\title{
Ice Jam Modelling of the Lower Red River
}

\author{
Karl-Erich Lindenschmidt ${ }^{{ }^{*}}$, Maurice Sydor ${ }^{2}$, Rick Carson ${ }^{3}$, Robert Harrison ${ }^{1}$ \\ ${ }^{1}$ Manitoba Water Stewardship, Winnipeg, Canada \\ ${ }^{2}$ Environment Canada, Sustainable Water Management Division, Ottawa, Canada \\ ${ }^{3}$ KGS Group, Winnipeg, Canada \\ Email: *Karl-Erich.Lindenschmidt@gov.mb.ca
}

Received October 25, 2011; revised November 26, 2011; accepted December 27, 2011

\begin{abstract}
The lower reach of the Red River between Winnipeg and Lake Winnipeg is very prone to ice jam flooding. The onedimensional ice jam model RIVICE was implemented for this reach to better understand the processes leading to such events and to provide a tool to evaluate strategies for ice jam mitigation. The most downstream portion of this river stretch flows through a delta and marsh system which poses challenges in modelling ice jams in such an area of low-lying topography and river banks. Solutions to overcome these challenges are discussed in this paper and results of one such solution using water abstractions from the main channel are also presented. Abstractions are inserted in the model to represent under-ice leakage from the main channel to side channel storage and diversions (up to $65 \%$ in the Red River delta) and spillage into the delta floodplain.
\end{abstract}

Keywords: Ice Jam Modeling; Netley Creek; Letley-Libau Marsh; Red River Delta; RIVICE

\section{Introduction}

Ice jams are a common occurrence during the onset of spring flooding along the Lower Red River, the mostdown-stream reach of the Red River between Winnipeg and Lake Winnipeg. Ice jams have occurred in this area for all of recorded history [1,2] and are a frequent problem in regards to local flooding. Trends show that the spring flood hydrographs begin earlier and rise steeper than in past decades causing break-up to be more severe and prone to ice jamming [3].

Due to the increasing frequency and severity of ice jam flooding along the Lower Red River, the Manitoba Government committed to expand its computer modelling repertoire to better understand the formation and behaviour of ice jams along the Red River: "Considerable work is underway through Manitoba Water Stewardship to understand the mechanisms of ice formation on the Red River. Computer models are being developed to simulate the evolution and behaviour of ice jams along the Red River" [4]. The long extent of the Lower Red River $(\approx 75$ $\mathrm{km})$ required a one-dimensional approach (variables change longitudinally and are averaged at each cross-section) to be taken for such a modelling exercise in order to reduce computational expenditure and minimise data input. The most downstream portion of the reach flows through a delta, which caused particular challenges in modelling ice jams in this area. Those challenges and solutions to

${ }^{*}$ Corresponding author. overcome them will be addressed in this paper.

Comparable studies of one dimensional ice-jam modelling in river deltas are sparse in the literature. One prevalent study is ice jam modelling of the Peace and Athabasca River delta [5]. The paper highlights limitations in modelling such an area with low-lying topography and river banks, in particular "floodplain truncation and consequent neglect of overbank flows at high stages" (p.3691). In addition, "distributed flow sinks due to overbank flow [were] ignored because there [was] no known method to quantify such sinks and the overbank topography [was] not known in sufficient detail" (p.3691). "Neglect of such flow withdrawals from the main river can have significant impacts on modelling results" [6].

\section{Study Area}

\subsection{Site Description (See Also [7])}

The Lower Red River is the most downstream reach of the Red River extending from the Assiniboine River confluence in Winnipeg (The Forks) to the Red River outlet at Lake Winnipeg (see Figure 1). The total drainage area of the Red and Assiniboine river watersheds is approximately $287,500 \mathrm{~km}^{2}$. The average flow at Lockport is $244 \mathrm{~m}^{3} / \mathrm{s}$ where maximum and minimum flows of 4330 and $14 \mathrm{~m}^{3} / \mathrm{s}$, respectively, have been recorded.

A lock and dam is situated at Lockport, which was built in 1910 to allow navigation along the river between Winnipeg and Lake Winnipeg. The dam has steel cur- 
tains that dam the river for navigation and roll up to allow flood waters from the spring freshets to pass. The lock and dam was built to allow navigation over a series of five rapids including an approximate $4 \mathrm{~m}$ drop in elevation around Lister Rapids. Just downstream of Lockport is the outlet of the Floodway, a channel that diverts spring floodwaters from the Red River south of Winnipeg to protect the city of potentially high flooding. Between Selkirk and Lake Winnipeg, the river flows through a delta system called the Netley-Libau Marsh. The marsh is very flat and consists of many small bodies of water interconnected by a network of channels with the Red River. A $400 \mathrm{~m}$ long cut, Netley Cut, short-circuits water from the river into Netley Lake.

A longitudinal profile of the river's thalweg and ice cover level, typical at the end of winter, is shown in Fig- ure 2. Generally at the end of winter, the water level gradient between The Forks and Lister Rapids is low $(\approx$ $0.00005 \mathrm{~m} / \mathrm{m}$ ). The river bottom becomes steeper between Lister Rapids and Lockport and the water level, too, at the end of winter, is steeper $(\approx 0.00015 \mathrm{~m} / \mathrm{m}) \mathrm{com}$ pared to the rest of the river stretch. Due to backwater effects from Lake Winnipeg, the water level gradient along the most downstream portion of the river, between Lockport and Lake Winnipeg, is essentially almost flat $(<0.00001 \mathrm{~m} / \mathrm{m})$.

\subsection{Lower Red River Ice}

The ice cover season along the Lower Red River typically extends from November to April. The ice cover is generally smooth, and once formed, tends to remain in place through the entire winter and has been measured to

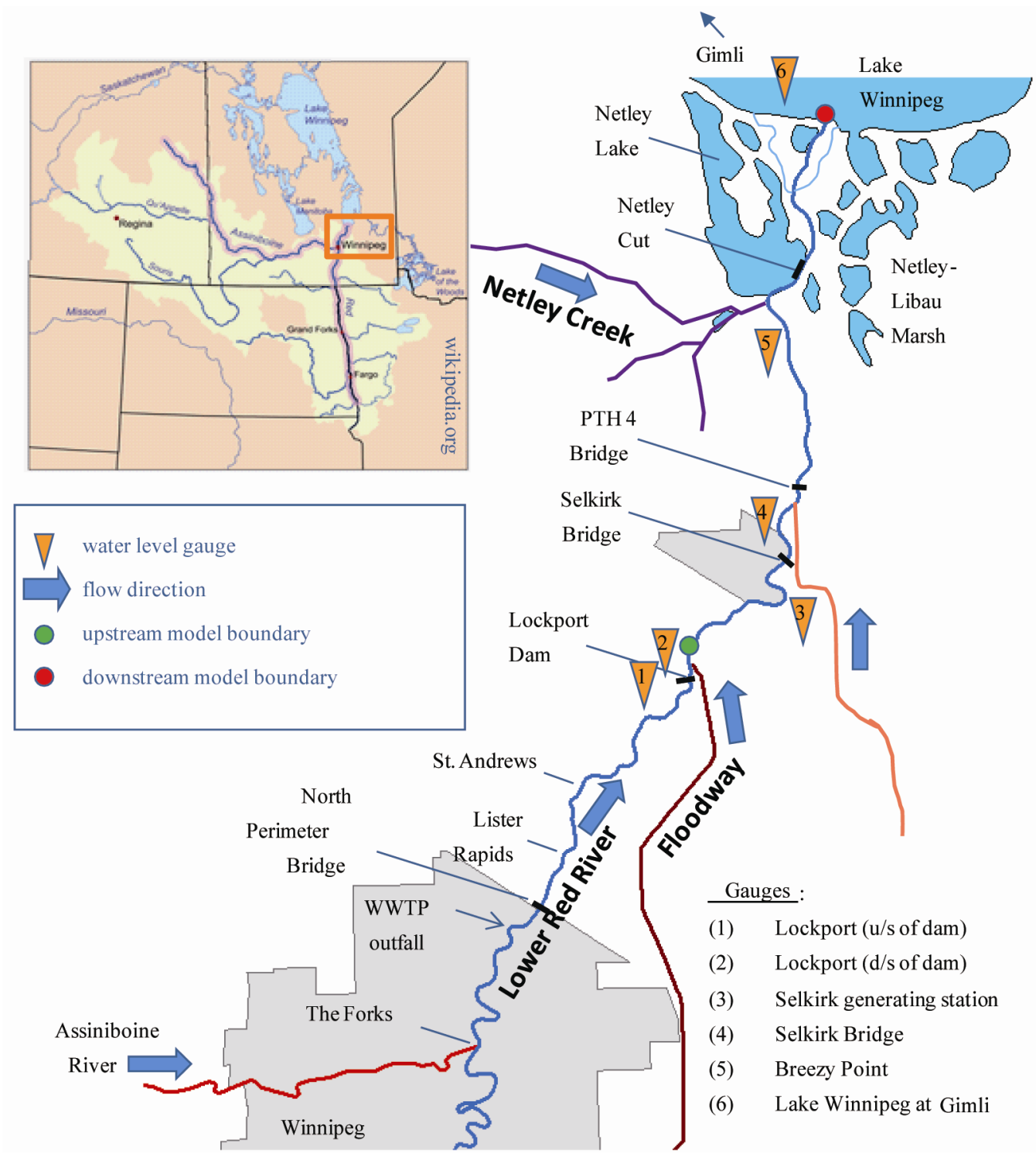

Figure 1. The lower Red River between the Forks in Winnipeg and Lake Winnipeg. 


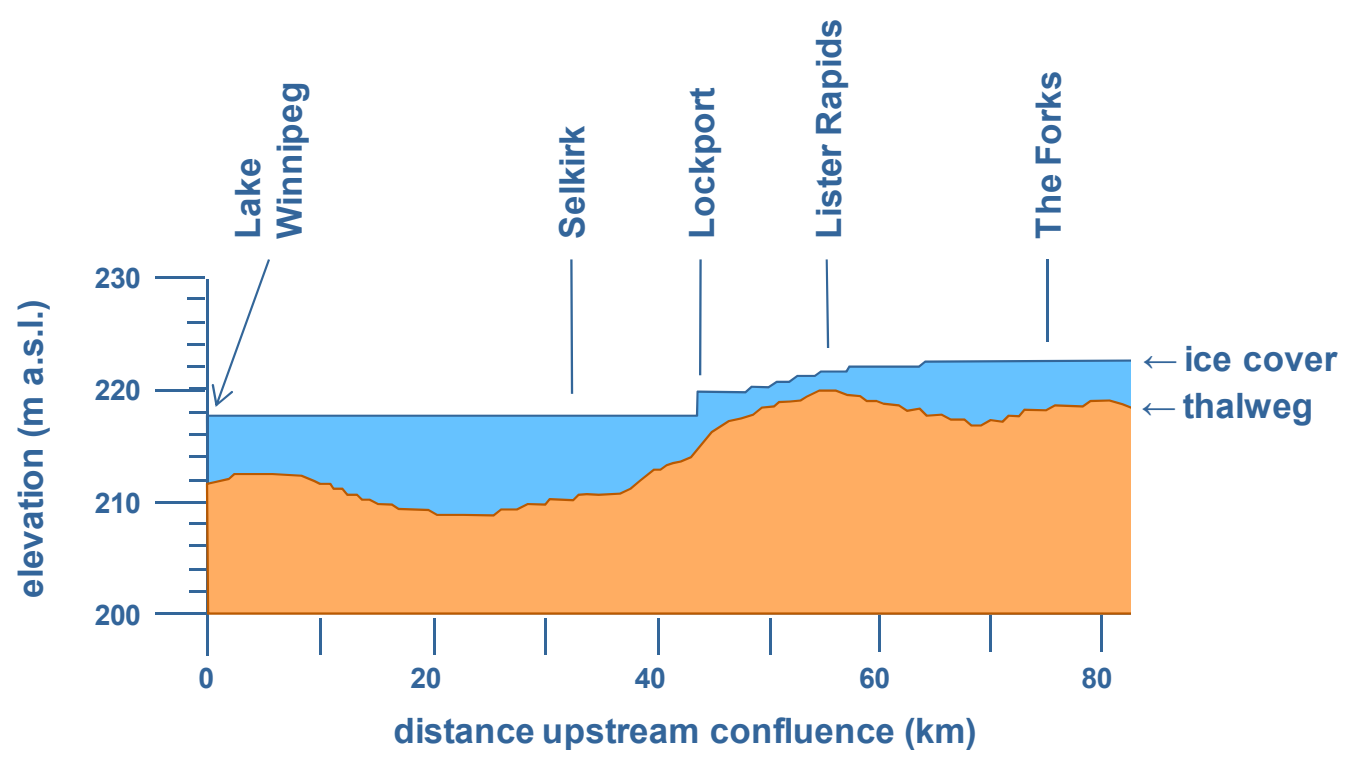

Figure 2. Longitudinal profile of the Lower Red River's thalweg and typical winters' end ice cover level (modified from Geological Survey of Canada http://gsc.nrcan.gc.ca/floods/redriver/geomorphology_e.php).

be up to $1 \mathrm{~m}$ thick in this region. Spring flooding is frequently exacerbated by mechanical ice breakup and ice jamming, especially during early and rapid melt events. Since recorded history, ice jams have plagued this area. The river at Selkirk and north of Selkirk are particularly prone to ice jam flooding. Historical newspaper articles indicate that serious ice jams occurred on the Red River near Selkirk as early as the mid to late 1800s [4].

Ice breakup has been found to usually occur in the 990 $\mathrm{m}^{3} / \mathrm{s}$ to $1420 \mathrm{~m}^{3} / \mathrm{s}$ range. Historically, locations most prone to ice jamming are at the Selkirk Bridge, Sugar Island, PTH 4 Bridge and downstream of the PTH 4 Bridge. In the Breezy Point to Netley Creek area, break-up likely occurs at somewhat higher flows (up to $2690 \mathrm{~m}^{3} / \mathrm{s}$ )) as the ice in this area is typically more competent "lake" ice [1].

Typically, the ice cover initially opens at the North Perimeter Bridge and over the next few days ice moves in the reach between the North Perimeter Bridge and Selkirk. An early rain event may exacerbate this situation. On occasion, ice jams along this stretch cause local flooding, as was the case along River Road in the spring of 2009. The ice movement is arrested at Selkirk to form a jam. This may occur first at the Selkirk golf course (immediately upstream of the Selkirk Bridge), and progress downstream to the Selkirk Bridge and Sugar Island. This usually causes flooding of the east approach to the Selkirk Bridge requiring the bridge to be closed to traffic. The jam pushes past Sugar Island to the PTH 4 Bridge.

Parallel to these events, the ice cover may break up north of PTH 4 Bridge and cause jamming at various points downstream to the Netley Creek confluence. Ice then moves further downstream and its initial surge is diverted into Netley Lake through Netley Cut. Jamming in this area very often is accompanied by water backup into Netley Creek causing local flooding. Recent years of severe ice jamming with flooding are 1996, 2004, 2007, 2009, 2010 and 2011. Attention will be focused on the ice jamming during the 2010 spring break-up of the ice cover along the Lower Red River.

\subsection{Break-Up of Ice in $\mathbf{2 0 1 0}$}

Artificial ice cutting and breaking was carried out 1-20 March 2010. Ice cutting was carried out from just south of Selkirk to Netley Marsh. Ice breaking took place between Netley Creek and Netley Cut, at Netley Lake, McIvor Lane and PTH 4 Bridge to Selkirk.

A rainfall event occurred on 10 March which was followed by a week of above $0^{\circ} \mathrm{C}$ daytime temperatures. Snowmelt occurred rapidly with no snow recorded on the ground at the Oakbank weather station by 18 March. The increased runoff caused the ice cover to open up at North Perimeter Bridge and the ice cover break-up progressed downstream until its front reached St. Andrews on 16 March and south Selkirk on 23 March. Figure 3 provides a SPOT-5 satellite image with the ice accumulation front at St. Andrews and Figure 4 shows a RADARSAT2 satellite image with the ice jam at south Selkirk.

The ice cover shown in the RADARSAT-2 imagery has a smooth texture consisting predominantly of columnar ice [7]. A RADARASAT-2 image acquired on 6. March along the same river stretch allowed ice thicknesses to be calculated from the image signals [3].

The ice jam at south Selkirk released on 24 March and the ice cover continued to break-up until Selkirk Park. Ice jamming occurred at this location and remained in place until 27 March. During this time, fragmented ice 


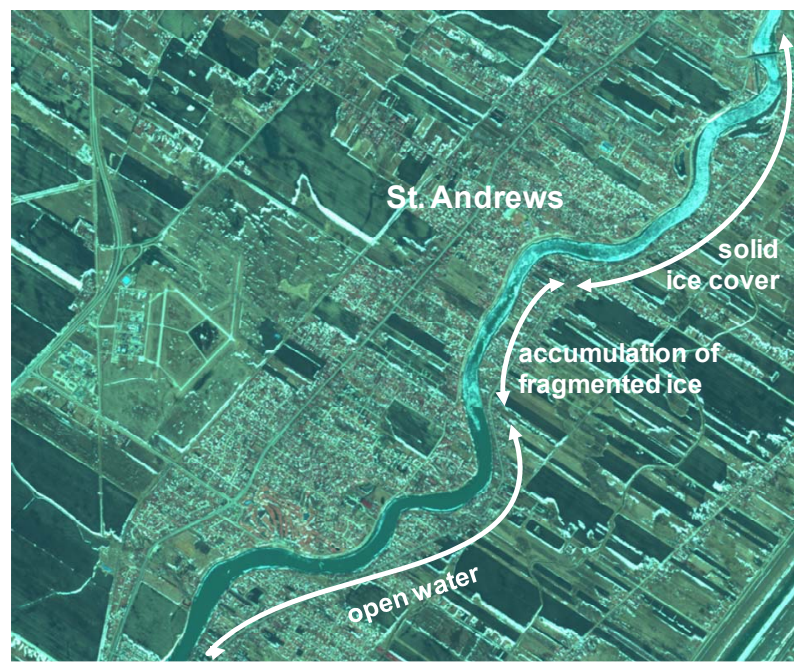

Figure 3. Multispectral SPOT-5 image of ice accumulation front at St. Andrews on 16 March 2010 (SPOT-5 image $($ ) 2010 CNES, Licensed by Iunctus Geomatics Corp, www. terraengine.com).

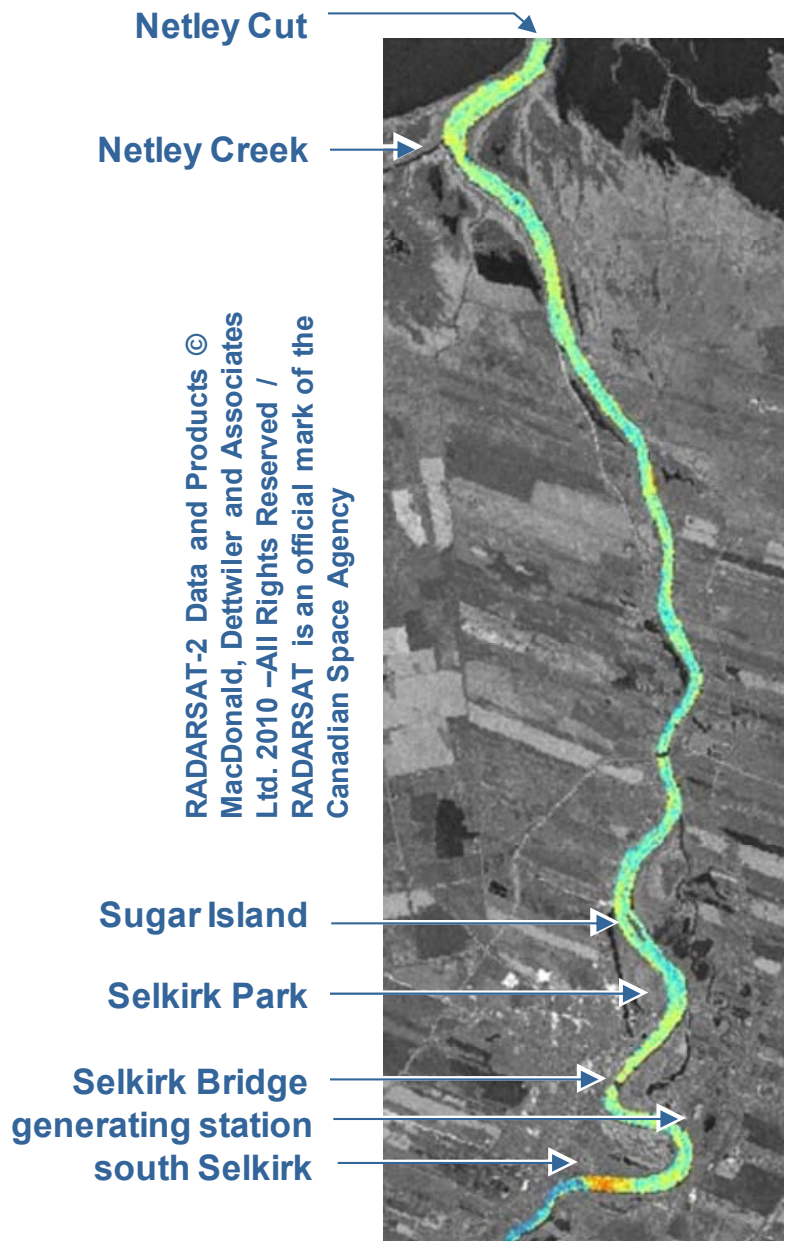

Figure 4. RADARSAT-2 image of the Red River ice cover between Selkirk and Netley Cut on 23 March 2010. The bright orange signal at south Selkirk indicates the ice jam. from upstream accumulated at the ice jam, whose front juxtaposed upstream past the Selkirk Bridge almost reaching the Selkirk Generating Station. A SPOT-5 image of ice jam extension from its toe at the park to its front at the generating station was captured on 26 March and is shown in Figure 5. This is the ice jam that serves as one of the modeling case studies described below.

The ice jam at Selkirk Park released on 28 March and the ice flowed downstream to jam again for a short period at the PTH 4 Bridge. By 29 March, this jam released and the ice cover front moved downstream to cause a jam at Netley Cut. The river reach between the Netley Creek confluence and Netley Cut is particularly susceptible to ice jams for several reasons:

1) Tributary sediment export-Netley Creek drains a large agricultural area and much sediment is deposited into the Red River just downstream of the creek outlet into the Red River. An increase of up to 4 to $5 \mathrm{~m}$ in bed elevation is consistently measured in the flow direction as Red River water passes the Netley Creek confluence.

2) Sharp meander - the meander of the Red River at the Netley Creek outlet is very tight which can constrict the flow of water and ice during spring break-up of the ice cover.

3) Low slope - water level gradient along the most downstream portion of the river is almost flat $(<0.00001 \mathrm{~m} / \mathrm{m})$.

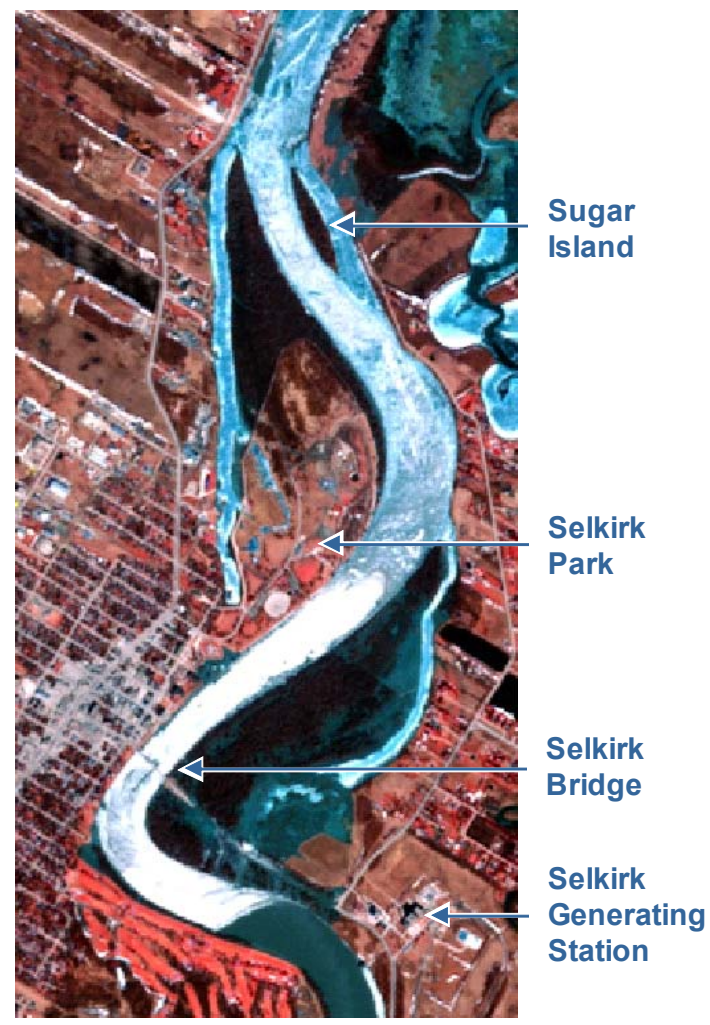

Figure 5. SPOT-5 image of ice jam at Selkirk on 26. March 2010 (SPOT-5 image (c) 2010 CNES, Licensed by Iunctus Geomatics Corp, www.terraengine.com ). 
An aerial photograph of the ice accumulation at Netley Cut is shown in Figure 6. The photo shows ice fragments from the jam spilling through Netley Cut into Netley Lake. The ice jam produced the highest stages on record along the east bank between Selkirk and Breezy Point. Minor flooding occurred at Petersfield due to the ice jam backing water into Netley Creek. This ice jam is the second modeling test case described below. By 31 March, all the ice had cleared from the river up to its confluence at Lake Winnipeg, which usually maintains its ice cover into May.

\section{RIVICE Model}

In general, RIVICE [8] is a one-dimensional hydrodynamic computer model which uses an implicit finite-difference scheme to simulate major ice phenomena and processes along rivers. This includes ice cover formation and ablation, frazil ice formation, border ice advancement, anchor ice, ice transport, hanging dams, break-up and ice jams.

The fundamental premise of the RIVICE software is that the calculations of ice generation and evolution can be separated from the hydraulic processes (water surface profiles, changes in flow and water level, etc.) if they are done frequently. This is a so-called "loosely-coupled" relationship between the ice and the hydraulics, even though the changed ice conditions are directly introduced into the hydraulic solution at each computation cross-section and every time-step. Under very rapid jamming conditions, the time-step varies from minutes to seconds to best capture these rapidly changing ice events. It does not require a complex simultaneous solution of ice and hydraulic equations. However, the user must make a careful selection of the length of time step that suits the situation at hand.

\subsection{Ice Cover Setup}

An ice cover on flowing water is subjected to hydraulic

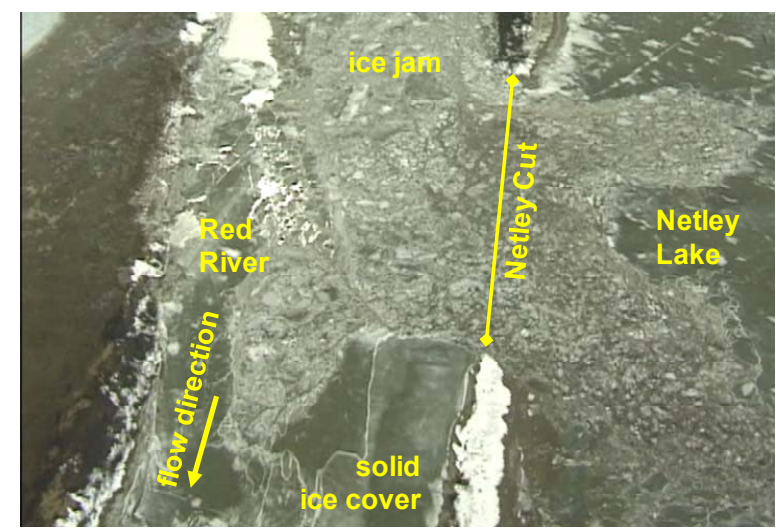

Figure 6. Ice jam at Netley Cut on 29 March 2010. Some fragmented ice has spilled through the cut into Netley Lake. forces which can cause deformation and thickening. The algorithm used in RIVICE involves the incremental summation of computed forces on the ice cover in a stepmode beginning from the leading edge and advancing from cross-section to cross-section in the downstream direction. The forces include:

1) Hydrodynamic thrust on the leading edge;

2) Hydraulic drag of the flow on the ice under surface;

3) Component of weight of the ice cover and the water contained in its voids, acting along the hydraulic gradient;

4) Force shed to the river banks which includes cohesion of the ice cover to the banks acting as a frictional force of the ice cover against the banks;

5) Hydraulic forces exerted on the ice cover in the stream-wise direction create stresses in the ice, which are spread laterally towards the riverbanks. The lateral stress results in a reaction of static friction at the bank, which acts as a stabilizing influence on the cover.

As the calculation proceeds downstream, the stress in the ice cover $f_{i}$ is determined from:

$$
f_{i}=\left(F_{t}+F_{d}+F_{w}-F_{c}-F_{f}\right) / t B
$$

where $t$ is the ice thickness and $B$ is the width of the ice cover. If the stress exceeds the maximum resistance of the ice cover, shoving or telescoping of the ice must occur to attain the minimum required thickness. The simulation of a shove is done by:

- Thickening of the ice cover at an unstable location (i.e. stress in ice cover exceeds its internal resistance) to achieve a stable thickness; this may be restricted in any given time step by the maximum rate of movement of the ice as described below;

- Reduction in ice volume at the leading edge to be equivalent to the volume required to thicken at the unstable location (a downstream "recession" of the leading edge results).

The volume of ice which is supplied to thicken the cover at an unstable location is limited by the maximum rate of movement of the ice cover, estimated to have a maximum speed equal to the average flow velocity. This represents an upper limit to the volume of ice that can move in a shove during a time step.

\subsection{Deposition/Erosion of Ice Cover}

Deposition of ice on the underside of a stationary ice cover occurs if the average flow velocity of the water is below a computed or specified threshold $v_{\text {dep }}$ (default $=$ $1.2 \mathrm{~m} / \mathrm{s}$ ), and there is ice-in-transit under the ice cover at that location. If this velocity is exceed, deposition will be truncated and the ice that is in transit will continue to travel downstream.

If the velocity and shear stresses are large enough, erosion of the established ice cover can occur. Erosion of 
the ice cover is simulated if the velocity exceeds a computed or specified limit $v_{\text {erosion }}($ default $=1.8 \mathrm{~m} / \mathrm{s}$ ) [9]. The ice will be thinned until the velocity reaches the specified limit. If an ice cover reaches a thickness that is less than $0.15 \mathrm{~m}$, the erosion process is truncated at that point.

\section{Data for Model Setup}

The model extended from its upper boundary just downstream of the Lockport Dam and the Floodway confluence (see Figure 1) to its lower boundary at the Red River confluence at Lake Winnipeg. Cross-sections of the river bed were available with average $250 \mathrm{~m}$ spacing from a bathymetric survey, but extended only from the upper model boundary to just upstream of the Breezy Point gauge. Additional bathymetric soundings from the Netley Creek confluence, Delta Forks and Red River confluence at Lake Winnipeg were made available by Public Works and Government Services Canada. An example of river bed elevation contours extracted from the soundings data acquired at the Netley Creek confluence is shown in Figure 7.

All gauge locations are indicated in Figure 1. Discharges recorded at the Water Survey of Canada gauging station Red River at Selkirk located near the Selkirk Bridge were used for the upstream model boundary (see Figure 8). Discharge readings between 24 and 31 March are erratic due to ice run and jam activity. A polynomial function was fit to the hydrograph from which model input discharges were extracted (verified by water balance).

Water levels recorded at Gimli on Lake Winnipeg were used for the downstream model boundary. Water levels of several gauges along the river were used to re-construct the occurrence of ice jams and to calibrate the model. These include the gauges at Lockport, both upstream and downstream of the dam, Selkirk generating station and Breezy Point.

Ice thicknesses were extracted from RADARSAT-2 satellite imagery (method description in [3]). A longitudinal profile of the average ice thicknesses of the Lower Red River is provided in Figure 9.

\section{Results and Discussion}

\subsection{Ice Jam at Selkirk}

Figure 10 shows, for a discharge of $1000 \mathrm{~cm}$, the longitudinal water level profiles along the modeled river stretch for three cases: open water conditions, an ice cover only and an ice cover with an ice jam at Selkirk. The model was first run under open water conditions without any ice on the river stretch, until a steady state was achieved (blue line). An ice cover was then inserted in the model during the simulation. The model was then allowed to continue to run until a second steady state
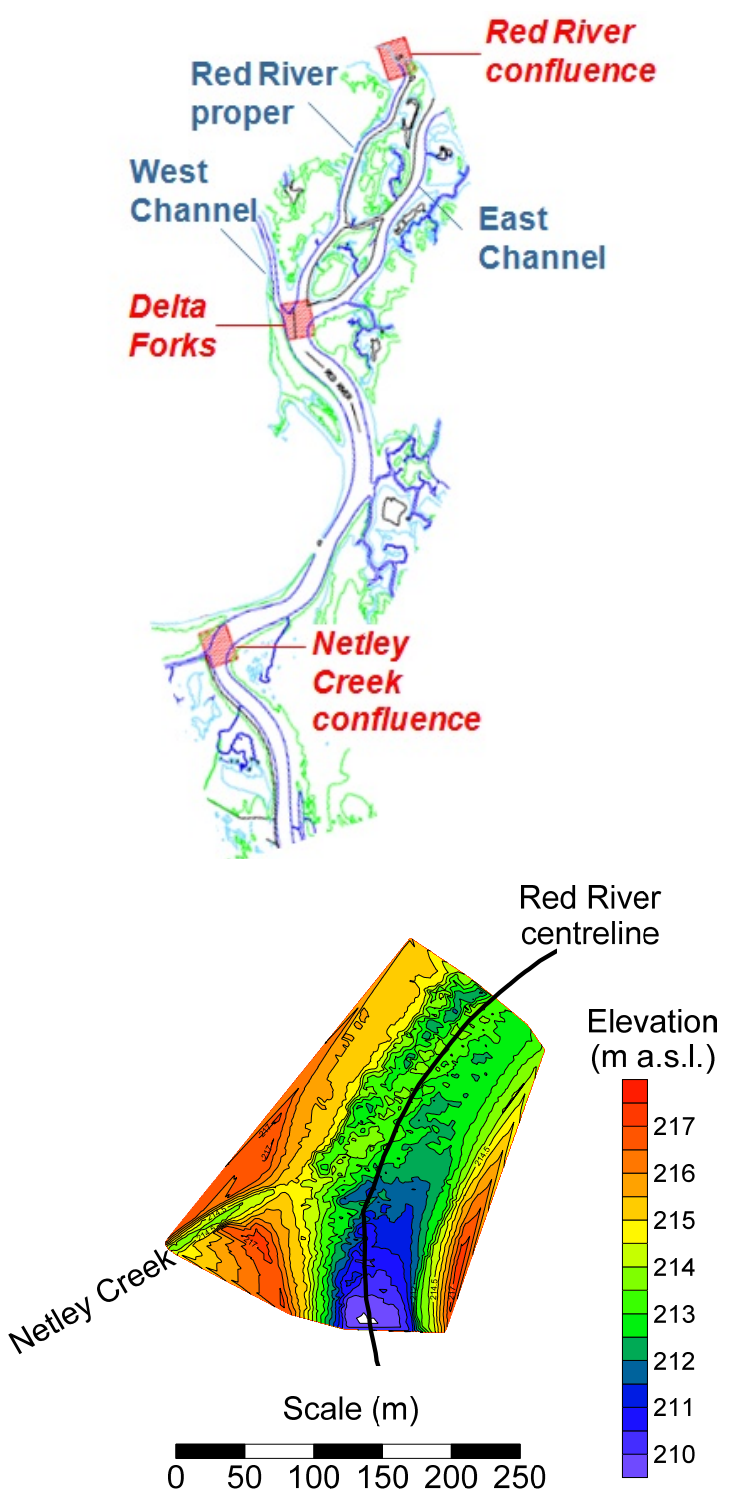

Figure 7. Location of soundings (top panel) with a zoom of the contour bathymetry at the Netley Creek confluence (bottom panel) (data purchased from Public Works and Government Services Canada).

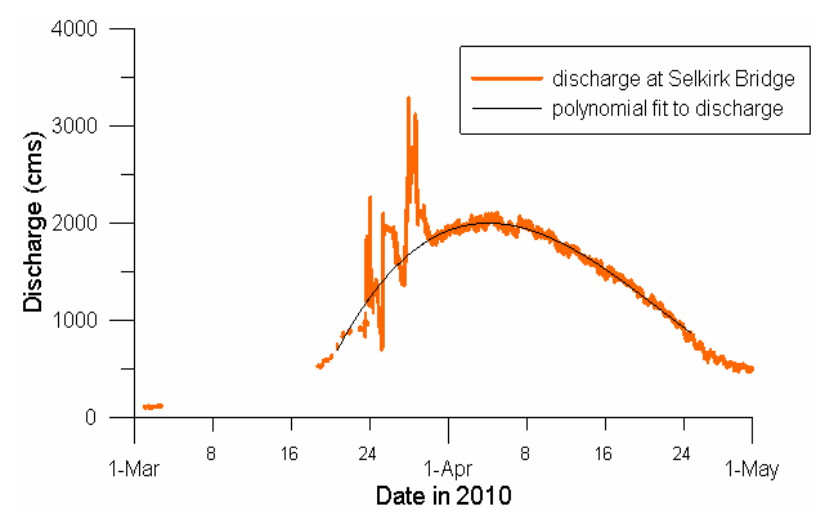

Figure 8. Discharge at Selkirk Bridge gauge (source: WSC). 


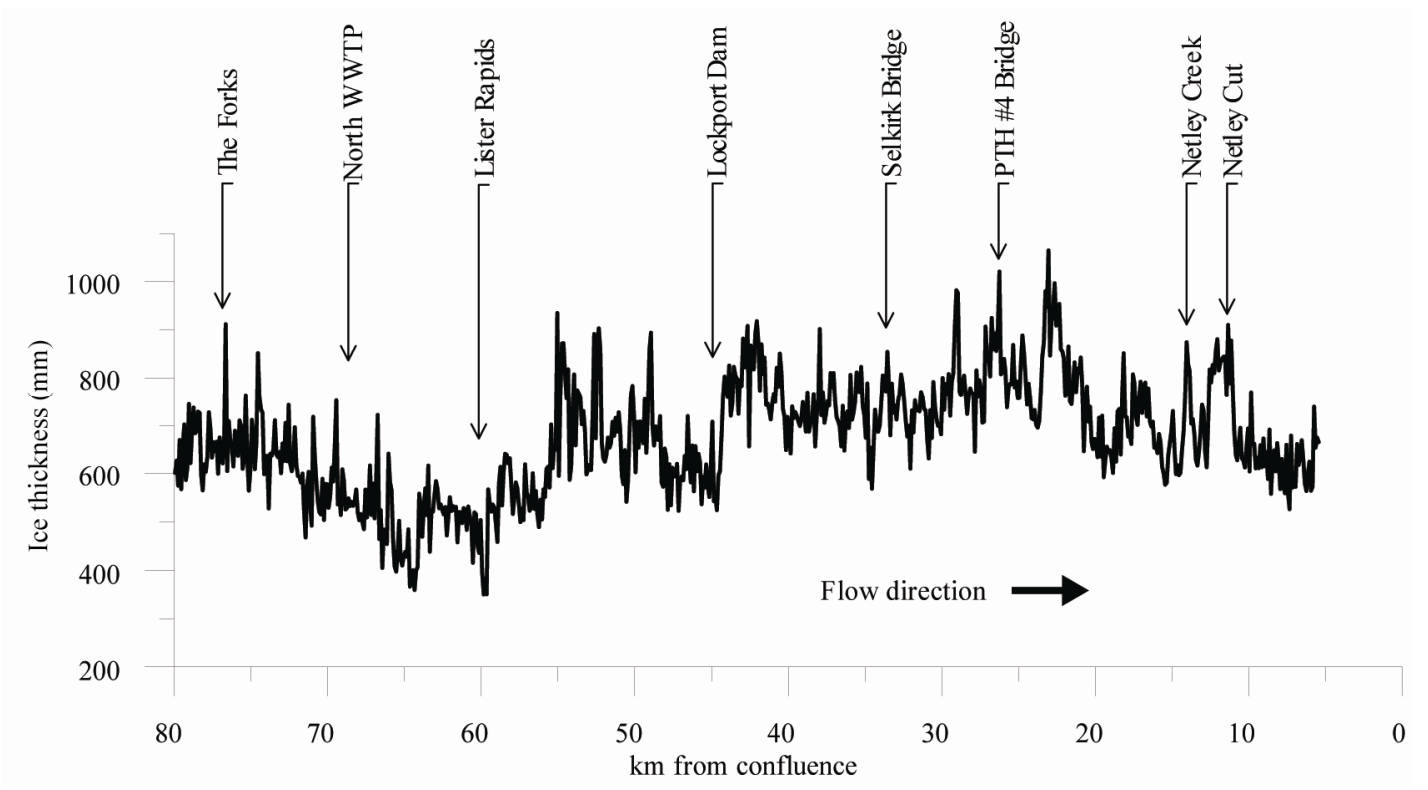

Figure 9. Longitudinal profile of average ice thicknesses of the Lower Red River between the forks in Winnipeg and just upstream of the river's confluence at Lake Winnipeg.
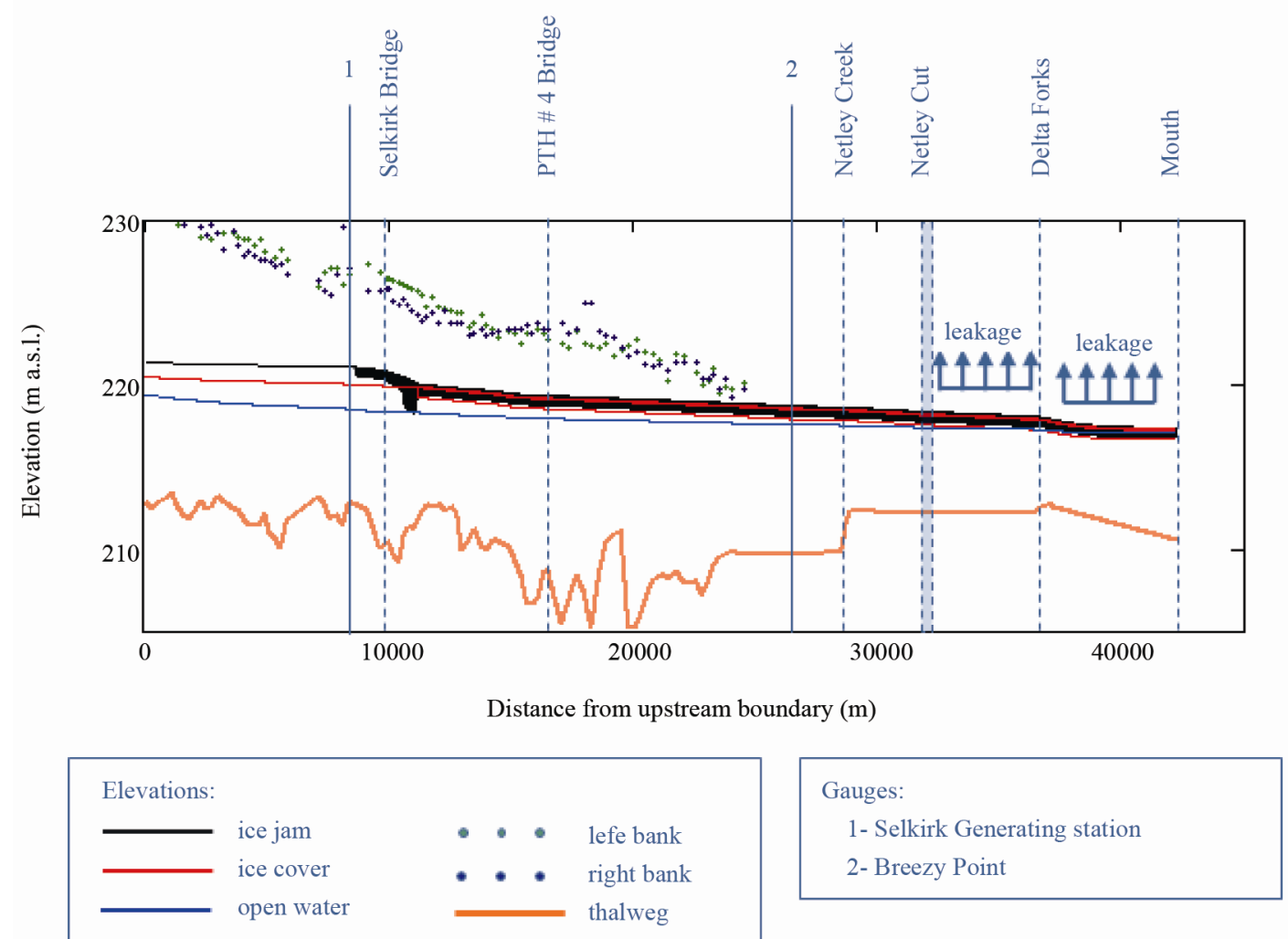

Figure 10. Simulated longitudinal profiles for open water conditions, ice cover and ice cover with ice jam at Sugar Island on 25 March 2010.

condition was attained resulting in an increased water level profile due to the backwater effects caused by the flow under ice (red line). A flow of ice was then inserted that lodged at the ice cover front and formed an ice jam.
The volume of ice corresponds to the amount of ice that broke up between Lockport and Selkirk. The simulation was allowed to persist until another steady state was achieved. The resulting profile of the backwater levels 
(black line) and the thicknesses of the ice cover and ice jam (black infills) are included in the figure. Notice that the ice jam and its backwater effects are well within the banks of the river.

The simulations were repeated for increasing discharges on successive days, and the simulation results are juxtaposed on corresponding hydrographs in Figure 11. There is very good agreement between model results and recorded water levels.

Water level readings from the Breezy Point gauge were drawn upon to determine model simulation outcome along the ice cover downstream from the ice jam. An initial simulation with the river modelled as a single channel to its mouth at Lake Winnipeg resulted in over-estimating the water levels with an intact ice cover at Breezy Point. This is due to the constricted cross-sections of the Red River proper in its delta in the Netley-Libau Marsh area. In actuality, the flow of the river fans out into several side channels between Netley Cut and Lake Winnipeg (see Figure 1). Many of the shallow lakes in the marsh are also interconnected providing additional paths for water to flow from the Red River to Lake Winnipeg. Hence, for our one-dimensional model setup, a diffuse lateral abstraction was inserted between Netley Cut and Lake Winnipeg to represent the leakage of water away from the Red River proper. Calibration of the simulated water level to the gauge readings at Breezy Point resulted in a water leakage of $65 \%$ of the total inflow at the upper boundary. This is in line with leakages reported from other river deltas (e.g. Mackenzie River).

\subsection{Ice Jam at Netley}

In the evening of 28 March 2010, the ice jam at the Selkirk Bridge released, as shown in Figure 12 by the abrupt drop in water level recorded at the Selkirk generating station. The jave caused a sharp water level rise at

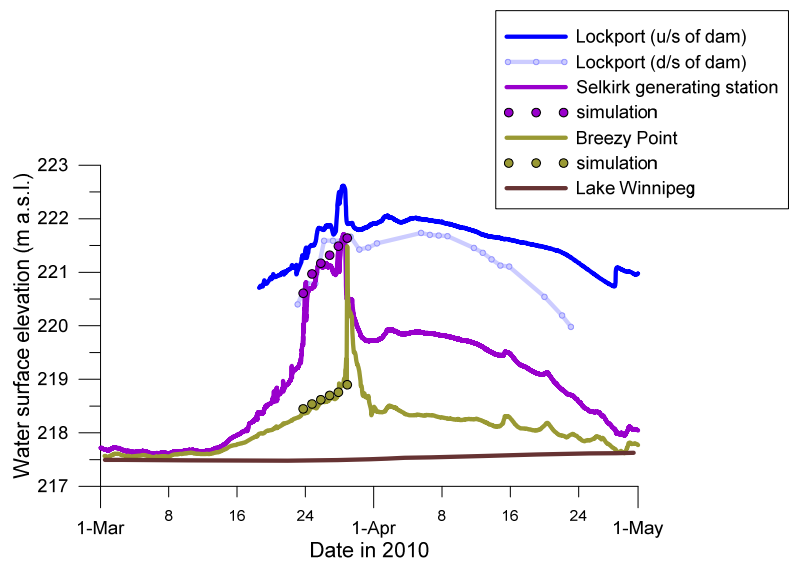

Figure 11. Recorded water levels during the spring flood of 2010. Simulation results pertain to the ice jam at Selkirk Park (data source: Water Survey of Canada and Manitoba Water Stewardship).

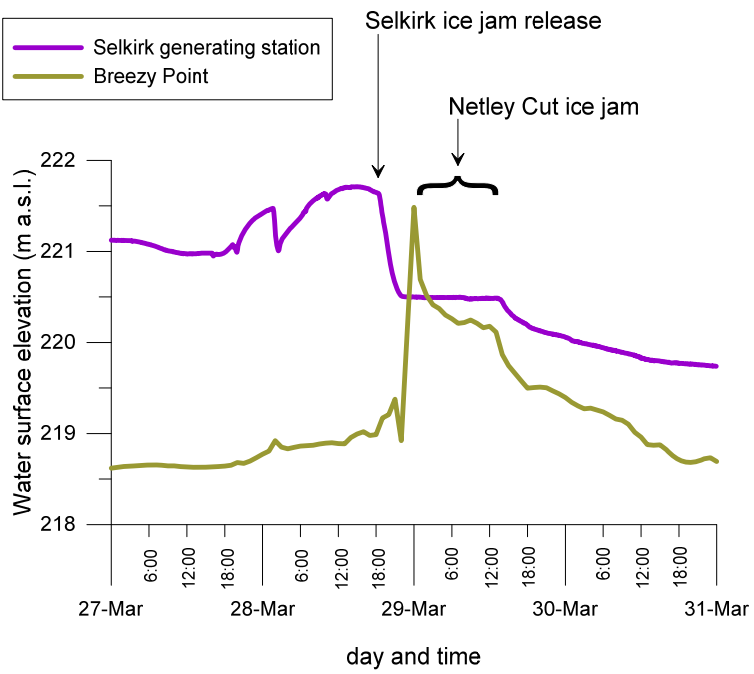

Figure 12. Water levels recorded at Selkirk generating station and the Breezy Point gauge during the ice jam released at Selkirk Bridge and the establishment of another ice jam at Netley Cut.

the Breezy point gauge approximately six hours later and the ice run was arrested at the Netley Cut where an ice jam was established until mid-day of 29 March 2010.

The model calibrated for the Selkirk ice jam was used as a basis for the model of the Netley Cut ice jam. The flow upstream of the jam release was approximately $1750 \mathrm{~m}^{3} / \mathrm{s}$ (see Figure 8), which was inserted as the upstream boundary flow. The water level at the downstream boundary at the Red River mouth at Lake Winnipeg remained unchanged. The volume of ice contributing to the Selkirk ice jam plus the ice that covered the river between the Selkirk Bridge and Netley Cut was input to the model.

Approximately $5 \mathrm{~km}$ upstream from the Netley Creek confluence, the widening of the floodplain adjacent to the Red River begins. This floodplain extends downstream into the Netley-Libau Marsh area, which forms the delta of the Red River. The river's banks are very low and the surrounding topography is also very flat and low lying. Hence, this floodplain is very prone to ice jam flooding. The concept is depicted in Figures 13(a) and (b) in which an increase in discharge will cause the ice cover to rise and break up. If the flow is a surge, which is the case when an upstream ice jam releases (e.g. at Selkirk), the in-channel storage capacity is quickly exhausted and the water spills into the surrounding floodplain or backs up into adjacent tributaries.

In the model, the width of the ice cover spans across the top of the entire cross-section provided as input. Only in-bank cross-sections are used since the ice cover width is contained within the river banks. The model assumes vertical walls extending upward from the leftmost and rightmost points of each cross-section to contain increased discharges, as shown in Figure 13(c). The water 
levels become too high, though, for an upstream ice jam release since water spillage into the large floodplain is not simulated. The water level profiles for this particular case for the Netley Cut ice jam is shown in Figure 14. The back water level just upstream of the ice jam front (black line) is almost $3 \mathrm{~m}$ higher than the backwater level cause by the downstream ice cover alone (red line) and $\approx 2.5 \mathrm{~m}$ above the left and right bank elevations. Extending the cross-sections in the model to include the floodplain, however, would also extend the ice cover width to the edges of the floodplain, as shown in Figure 13(d). This, too, veers from reality.

The approach taken here is to adapt the model to simulate more realistic ice jam flooding in this river section within a large floodplain by incorporating a diffuse abstraction of water from the river along the floodplain upstream of the ice jam, as depicted in Figure 13(e). The volume of water removed from the main channel represents both flood water spillage into the floodplain and leakage of main channel water into side channel storage and diversions. Resulting water level profiles are shown in Figure 15. The amount of water abstracted along the 5 $\mathrm{km}$ stretch upstream of the ice jam was varied until the backwater level coincided or was just above the most downstream left and right bank elevations available. This resulted in a total abstraction equalling $1 / 3$ of the upstream boundary flow. The leakage along the downstream ice covered portion of the river was reduced by half in order to avoid a drop in the downstream ice cover. This decrease in leakage is justified due to the reduced flow under the ice jam and the reduction in hydraulic head after the Selkirk jam release.

(a)

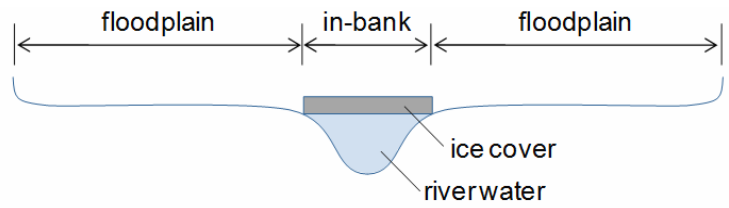

(b)

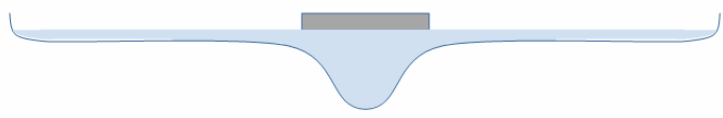

(c)

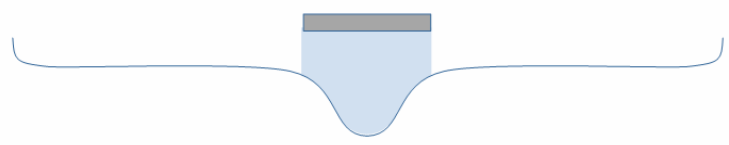

(d)

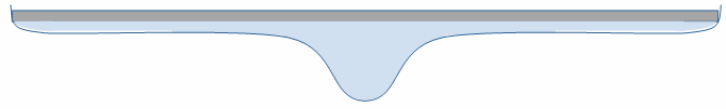

(e)

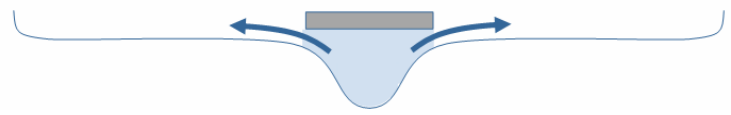

Figure 13. Conceptualizations of an ice covered river flooding its floodplain.

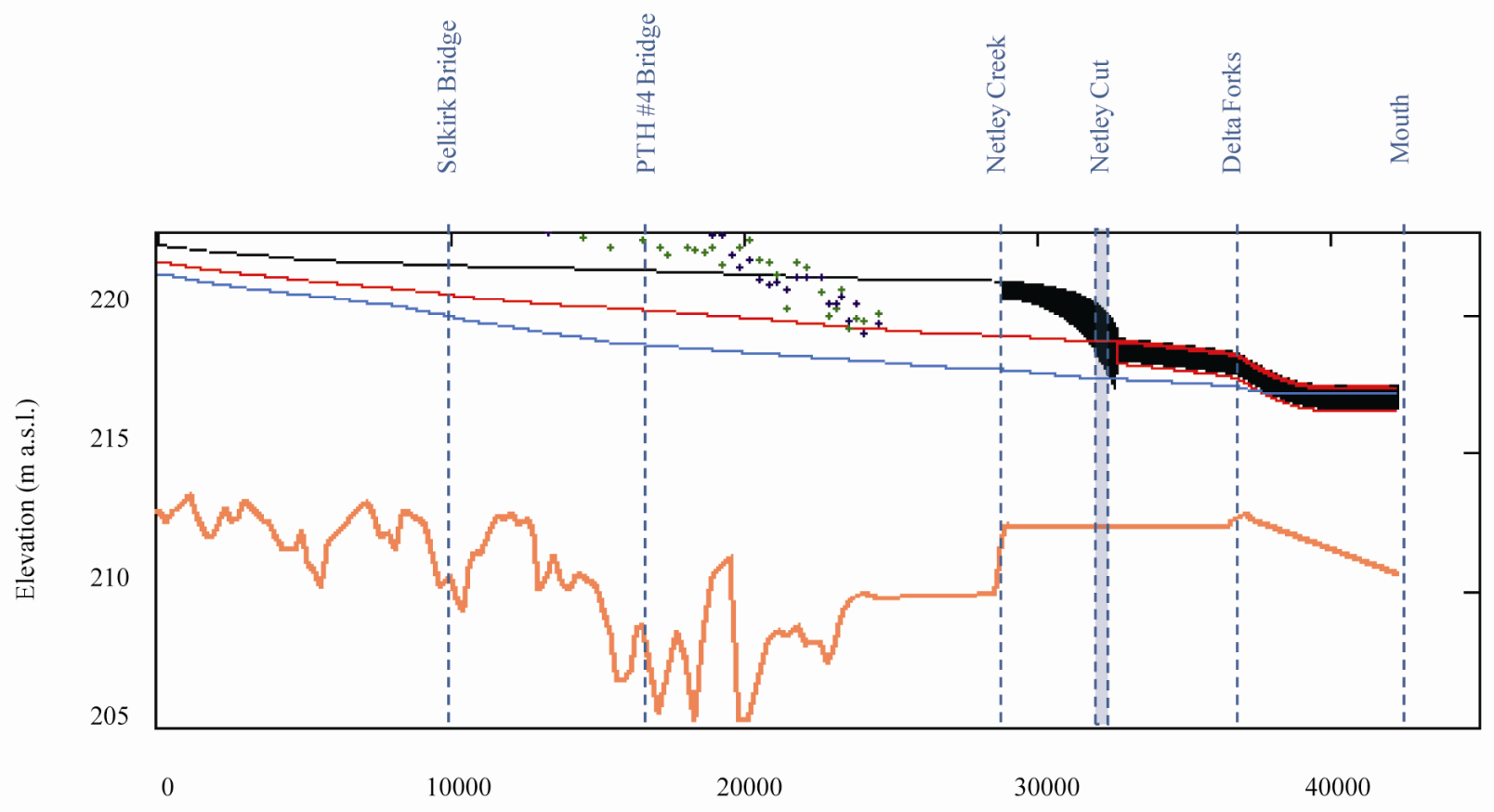

Distance from upstream boundary (m)

Figure 14. Simulated longitudinal profiles for open water conditions, ice cover and ice cover with ice jam at Netley Cut on 29 March 2010 without incorporating flood water spillage into floodplain (legend as in Figure 11). 


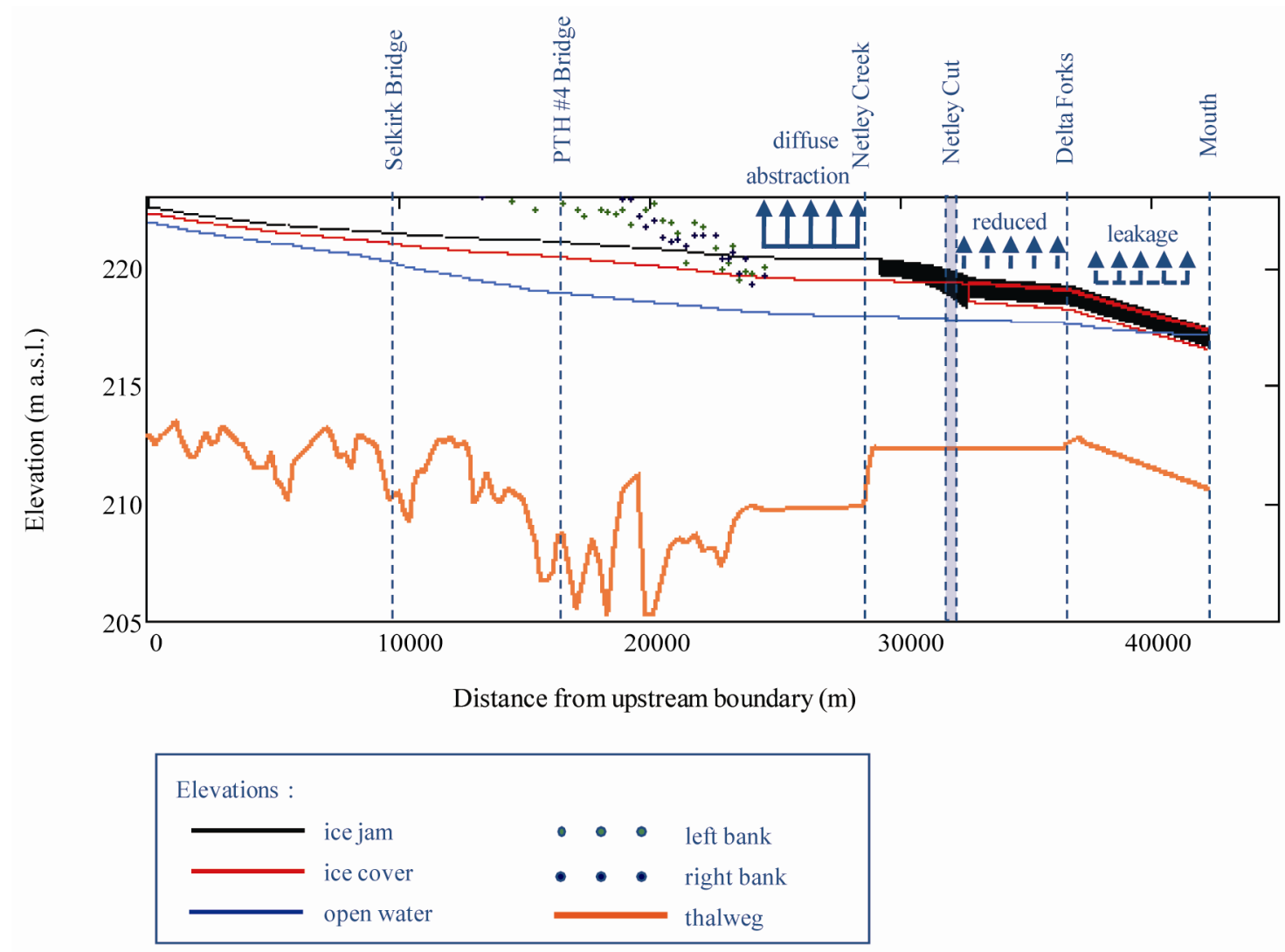

Figure 15. Simulated longitudinal profiles for open water conditions, ice cover and ice cover with ice jam at Netley Cut on 29 March 2010 with a diffuse abstraction of water equivalent to the volume of flood water spilling into the floodplain (legend as in Figure 11).

Another approach that may be implemented, and warrants future study, is inserting a tributary just upstream of the ice jam which has a storage capacity equivalent to the volume of water flooding the floodplain. The flow through the tributary would only be activated on the onset of jamming. Another approach described in the literature is taking "tributary flow reversals $\cdots$ into account by trying different plausible outflow amounts and settling on the set that [gives] satisfactory ice-jam profiles and waterlevel predictions" [5] (p.3696). Sequential model applications in sub-reaches between reversed-flow tributaries have resulted in satisfactory reproductions of peak water levels [5] (p.3700).

\section{Conclusions}

Rivers flowing through low-lying areas such as river delta poses particular challenges for ice jam modelling. One solution using main channel abstraction to represent bank overspill into a floodplain and leakage into side channels proved successful. Under-ice leakage from the Red River main channel was estimated through calibration to be as high as $65 \%$ of the upstream discharge. Leakage decreased as the ice jam front progressed further down- stream, thereby reducing the head differential between water levels upstream of the ice jam and the downstream ice-covered leakage area. Ice jam backwater spilling over low-lying river banks into the floodplain maintained this reduced head differential.

Simulating ice jams in the Red River delta area with a one-dimensional modelling approach was successful and a useful tool is now available to carry out scenarios to investigate various ice jam mitigation strategies. Important questions that may be tackled in future work include:

1) Where should efforts of artificial cutting and breaking of the ice cover be concentrated and avoided to reduce the hazard of ice jam flooding?

2) What impact would closing off the Netley Cut have on ice jam flooding risk?

\section{REFERENCES}

[1] Acres, Manitoba Floodway Expansion Authority-Floodway Expansion Project-Project Definition and Environmental Assessment, Preliminary Engineering Report Appendix L: Environmental Baseline Studies-Water Regime Effects, Final Report, Winnipeg, 2004.

[2] Farlinger and Westdal, "Red River Floodway public con- 
sultation on the rules of operation," Volume 1: Report on the public consultation. October 2010.

http://www.gov.mb.ca/waterstewardship/floodway_rules of_operation/documents/report_and_appendices.pdf

[3] K.-E. Lindenschmidt, G. Syrenne and R. Harrison, "Measuring Ice Thicknesses along the Red River in Canada Using RADARSAT-2 Satellite Imagery," Journal of Water Resource and Protection, Vol. 2, No. 11, 2010, pp. 923933. doi:10.4236/jwarp.2010.211110

[4] MB - Manitoba Government, Red River Floodway Operating Rules Public Review Report. 1. November 2010. http://www.gov.mb.ca/waterstewardship/floodway_rules of_operation/documents/report_on_floodway_operating_ $\bar{r}$ ules_public_review_nov_1_2010.pdf

[5] S. Beltaos, "Numerical Modelling of Ice-Jam Flooding on the Peace-Athabasca Delta," Hydrological Processes, Vol. 17, No. 18, 2003, pp. 3685-3702. doi:10.1002/hyp.1355

[6] M. N. Demuth, F. E. Hicks, T. D. Prowse and K. McKay, "A Numerical Modelling Analysis of Ice Jam Flooding on the Peace/Slave River, Peace-Athabasca Delta," PeaceAthabasca Delta Technical Studies-P-ADJAM, Subcomponent of Task F.2: Ice Studies, Peace-Athabasca Delta Technical Studies Appendices: I, Understanding the Ecosystem, Task Reports, National Hydrology Research Institute Contribution Series CS-96016, Saskatoon, 1996.

[7] K.-E. Lindenschmidt, J. van der Sanden, A. Demski, H. Drouin and T. Geldsetzer, "Characterising River Ice along the Lower Red River Using RADARSAT-2 Imagery," CGU HS Committee on River Ice Processes and the Environment (CRIPE), 16th Workshop on River Ice, Winnipeg, 18-22 September 2011.

http://cripe.civil.ualberta.ca/Downloads/16th_Workshop/ Lindenschmidt-et-al-2011a.pdf

[8] KGS, "RIVICE Software-User Manual," Draft Revision A, Vienna, 2010.

[9] B. Michel, "Winter Regime of Rivers and Lakes," U.S. Army Corp of Engineers. Cold Regions Research and Engineering Laboratory, Hanover, 1971. 